\title{
Toward a New Conditionality of Welfare? Reconsidering Solidarity in the Danish Welfare State
}

Hans-Jörg Trenz and Maria Grasso

\section{INTRODUCTION}

The Danish (Scandinavian) welfare model is based on the principle of universalism: providing equal services in the form of tax-financed benefits to all citizens independently of their individual contributions. Solidarity traditionally has a high value in the small and egalitarian Scandinavian societies and can rely on the homogenous composition of the populations in terms of ethnic, religious and linguistic unity. This is generally seen as generating high levels of support for the welfare state. At the same time, a strong and omnipresent welfare regime can be said to release citizens from the need to invest in substantive support action. The basic needs of vulnerable groups like the

\section{H.-J. Trenz $(\bowtie)$}

Department of Media, Cognition, and Communication, University of Copenhagen, Copenhagen, Denmark

ARENA, Centre for European Studies, University of Oslo, Oslo, Norway

M. Grasso

Department of Politics, University of Sheffield, Sheffield, UK

(C) The Author(s) 2018

C. Lahusen, M. Grasso (eds.), Solidarity in Europe,

Palgrave Studies in European Political Sociology,

https://doi.org/10.1007/978-3-319-73335-7_2 
unemployed, people with disabilities or refugees are served by the universal welfare state as a centralized care-taker for the well-being of society.

At the same time, the traditional inclusive welfare regime in Denmark has over the last decade undergone an important, and often unnoticed, transformation. In a series of reforms by the liberal-conservative coalition which governed the country from 2001 to 2011 and, again, since 2015, welfare services have, in general, become more conditional and distinctions between various layers of need have been introduced. The new conditionality of welfare services applies, for instance, in the labor market with an emphasis on 'flexicurity' and the measurement of individual contributions on which unemployment and welfare benefits are made dependent (Strøby-Jensen 2011). The inclusiveness of welfare state services has also been questioned with regard to the Europe of free movements, where the same rights apply indiscriminately to all EU citizens moving to and residing in Denmark.

In this chapter, we analyze engagement in solidarity actions in support of marginalized groups within the Danish population. We first provide an overall picture of the level of involvement of Danes in solidarity actions toward different kinds of vulnerable groups at the local, national, European and global level. Second, we look at how Danes contest solidarity toward these groups at different levels. The overall question to be examined is the inclusiveness of solidarity engagement within Danish society and the way in which solidarity in a traditionally welfare-generous country is currently performed in the backdrop of a European context that faces the challenges of migration, economic recession and increasing competiveness. It is argued that universal welfare states are put under pressure by such developments, first by external challenges and the necessity to respond to demands of new and increasingly diverse groups in need of assistance; and second, by the internal contestations of citizens who withdraw their support, oppose a further extension of welfare services and redefine solidarity.

\section{Contextualizing Solidarity: The Danish Case}

High-tax welfare states, like Denmark, arguably rely on strong ties of solidarity (Jöhncke 2011). The kind of solidarity ties that support redistributive welfare regimes must go beyond schemes of charity and include a notion of reciprocity in terms of sympathy felt toward co-citizens and a notion of shared responsibility in terms of acting together as a political community (Habermas 2013). Solidarity that supports redistribution 
therefore typically goes hand in hand with a strong civil society and with civic associations that promote trust and mutual support among the members of the political community (Banting and Kymlicka 2017; Hall 2017; Calhoun 2002). To make a strong welfare state sustainable, citizens should not only support the principle of reciprocal solidarity in abstract terms but also put it into practice in their daily interactions of mutual support and ties of sympathy among the citizens.

The advance of neoliberal market economies based on private initiative, including the cutting of public expenditures and deregulation, have posed a threat to this idea of civic solidarity (English et al. 2016; Grasso et al. 2017; Temple et al. 2016). Liberal market policies have been backed by all Danish governments over the last two decades and, in particular, by the liberal-conservative coalitions which have governed the country since 2001. As a consequence of such policies, Denmark has experienced a general retreat of universal welfare services with a new emphasis on individual responsibility (Jensen and Torpe 2016; Larsen et al. 2015). The weakening of social provisions of redistribution and a cutting down of welfare services can be expected to correlate with a decline of solidarity. Taxation as a core indicator to reciprocal solidarity (Stjernø 2004: 2) is challenged as fewer people are prepared to share resources with others, or simply because the capacities of the welfare state to redistribute income are limited. Strong and universal welfare states are in this sense particularly vulnerable, when their solidarity is tested by global developments or pressures of European market competition (Martinsen 2005). This holds in particular for a high-tax country like Denmark, which has adapted the universality of welfare services to the new flexibility of Europeanized and globalized labor markets. On the one hand, such transformations of the welfare state bear the risk of damaging traditional forms of centralized, universalistic solidarity, but, on the other hand, they also open the possibility that at the same time, and parallel or in direct response to Europeanization and market liberalization, new forms and practices of decentralized solidarity toward different groups of society may develop. European integration is in this sense perceived by some groups within Danish society both from the right and from the left as a major threat to national solidarity, but it could also lead to a general reorientation of solidarity practices. As such, solidarity becomes increasingly contested by new organizations and new forms of civic mobilization addressing European and global issues and increasingly operating at a European and global scale. In Denmark, such new solidarity contestations are proposed, on the one hand, by the Danish People's Party (Dansk Folkeparti) which is Denmark's second largest party, gaining 21.1\% 
of the vote in the 2015 general elections and supporting the current rightliberal minority government in Parliament. The Danish People's Party defends an exclusive notion of national solidarity as a community of belonging based on strong ethnic ties. It is opposed to strong and centralized welfare regimes emphasizing instead individual responsibility, subsidiarity and the need to cut down the high-tax burden in Denmark. In the European Parliament, the Party joined the Eurosceptic European Conservatives and Reformists group opposing EU sovereignty transfers, EU redistributive policies and European and global solidarity engagement. On the other hand, solidarity contestations are pushed by the political left, in particular by the Red-Green Alliance (Enhedslisten) gaining $7.8 \%$ of the vote in the 2015 elections. The left opposition emphasizes the fight against social inequality and poverty as one of their main priorities and is in favor of strengthening and expanding the welfare state. This includes solidarity toward marginalized groups, including foreigners and refugees. As such, Enhedslisten combines a perspective of national and global solidarity but is explicitly anti-EU and campaigns for a withdrawal of Denmark from its European commitments. ${ }^{1}$

Civil society associations have reacted to the new conditionality of the welfare state by shifting orientations and providing new services for the increasing number of those who are falling through the security net. As we are able to show in our survey of Danish civil society activism, solidarity actions by civil society organizations is shifting from being supplementary of state-based services to becoming more substantial and also more confrontational. Instead of assisting the state in implementing welfare, civil society is found to increasingly replace the state and to fight in opposition to state imposed restrictions and financial cuts (Duru et al. forthcoming; Spejlborg Sejersen and Trenz 2017).

The economic and financial crisis that was triggered in 2008 marks some further modest changes but not a radical rethinking of the Danish welfare regime. In general terms, Denmark has turned more restrictive toward vulnerable groups in society cutting welfare state expenditures and putting stronger emphasis on the obligation to work. As a result of the most recent policy changes, social benefits for the unemployed, refugees and people with disabilities persons have been cut or have become more conditional with preference given to measures that seek to reintegrate welfare recipients into the labor market. ${ }^{2}$ This is however in line with the tradition of the Danish welfare state, which has always combined a generous social safety net and free education with the obligations to pay high 
taxes and to contribute actively to the wealth of society through work, volunteering and social responsibility (Christoffersen et al. 2013).

The robustness of the welfare system in times of crisis can be explained by Denmark's efficient crisis management and quick economic recovery after having suffered from recession in the initial crisis years. Macroeconomic data shows, in fact, that the country and its population did not suffer from a substantial loss in wealth, and, while recession or economic stagnation were endured in many parts of Europe, Denmark soon profited again from economic growth. ${ }^{3}$ Denmark does not only continue to be the country with the most equal income distribution in Europe, its average annual wage is also one of the highest in Europe, while inflation is at an historical low. ${ }^{4}$ Unemployment is steadily declining since 2011 with a current unemployment rate (December 2016) of 6.5\%, which is below the EU28 average of $8.3 \%$ and far below the rate of countries most hit by crisis like Italy (11.9\%), Spain (19.1\%) and Greece (23.1\%). Youth unemployment is with $10 \%$ in 2016 far below the average in other European countries were the youth unemployment rate is generally double or more than double the unemployment rates for all ages. ${ }^{5}$ This downward trend indicates the recovery of the labor market which offers job opportunities for young adults not only from Denmark itself but also increasingly young mobile EU citizens. More recent periods (2011-2014) saw a strong increase in intra-EU mobility flows toward Denmark $(+44 \%)$, made up mainly by young adults in the East, South-East and South of Europe who escape economic hardship by moving to Denmark (European Commission 2014: 20-21).

In the field of immigration and asylum, we observe over the last five years a shift in the number of incoming migrants from non-EU to intraEU mobility, the former group discriminated by new restrictive legislation and the latter group profiting from the principle of nondiscrimination of EU citizenship and attracted by labor and education opportunities. ${ }^{6}$ These circumstances have become a concern for the Danish government and society, which-according to Jørgensen and Thomsen (2013) - is reflected in an increasing negative tone in the media toward both groups: EU and non-EU migrants. A more recent stage was marked by the arrival of refugees which has led to a political controversy regarding the humanitarian obligations of Denmark as well as with respect to solidarity within the EU. The Danish government's restrictive policies in the autumn of 2016 were criticized by neighboring Sweden and Germany and ultimately led to the suspension of Schengen rules of free movement and border control which still persists to this day. 
Despite these general challenges and tendencies in the transformation of the welfare state, Denmark remains exceptional in the European context in terms of the modest economic impact of crisis and de facto economic growth over the last few years. This might explain why the economic crisis also left only a low imprint on the attitudes of Danes, which remain strongly supportive of the high-tax and welfare regime, express high trust in the state, political parties and parliamentary representation ${ }^{7}$ and according to the World Happiness Report published annually by the United Nations Sustainable Development Solutions Network continue to be among the world's 'happiest nations'. Happiness, trust and life satisfaction have become a matter of national pride, and the good comparative rankings of Denmark are widely publicized and commented upon in the media and by political representatives. Our survey confirms these patterns, in terms of high life satisfaction, which is also backed by material gains: $72.5 \%$ of all Danes are satisfied or highly satisfied (6-10 on Likert scale) with their life (compared to $36 \%$ in Greece), and the great majority of Danes $(86.7 \%)$ declare that their financial situation has improved over the last five years (6-10 on Likert scale where 0 means much worse and 10 means much better), compared to only $11.4 \%$ in Greece.

In line with this image of Denmark as the worlds' happiest nation, a strong emphasis is placed on solidarity, which has two components: (1) support of redistribution measured, for example, in the willingness to share income through taxes and (2) trust and civic virtue, measured, for example, in the willingness to engage in solidarity action and contribute actively to the well-being of the community of citizens. This is often paired with an attitude of moralizing solidarity, that is, to emphasize the duties of active contributions to communal life and to blame deviants. Solidarity is a civic virtue but it is also a moral obligation. An attitude of moralizing solidarity can, in fact, be used as a justification of exclusive practices toward 'non-deserving' groups of society, an argumentation often used by populist-right parties. This raises the question whether there is a widening gap between perceptions of Denmark as the happiest country in the world and practices of exclusion toward growing numbers of poor or persons deprived of rights. The Danish pride in welfare and solidarity might thus nourish an illusion, if Danes continue to believe in the uniqueness of their welfare system and continue to trust in the state's capacities of care-taking while at the same time failing to recognize important systemic changes that put pressures on people in need, push more and more Danes into 
private insurance schemes or exclude them from the net of social security. As has been noted in a recent report published by a NGO active in the field:

\begin{abstract}
Although Danish society claims to uphold the basic principles of a welfare state-solidarity among citizens and provisions for the needy-in practice, public discourse and government policies have been creating a more libertarian, individualistic model that strays from its founding principles. Until the Danish people stop moralizing about solidarity and acknowledge the changing nature of their welfare system, Denmark's poor and excluded will grow in number to fill this dangerously widening gap between perception and practice. ${ }^{8}$
\end{abstract}

We have identified and described the changing state-civil society relations and new solidarity practices elsewhere (Duru et al. forthcoming; Spejlborg Sejersen and Trenz 2017). Based on these insights, it is now our task to analyze more closely public attitudes and public attention in relation to these new solidarity challenges and contestations.

We organize our analysis around a set of questions relating to the attitudinal and behavioral dimensions of solidarity. The question is whether public opinion is leaning more toward a universalistic or an individualistic welfare arrangement. Do Danes continue to support universalistic welfare or do they back the new state policies that make welfare conditional of contributions? Are Danes also aware of the European and global dimensions of solidarity and of the challenges and opportunities offered by European market integration? The question is further whether restrictions in welfare state services and policies that affect particularly vulnerable groups within society, such as refugees, migrants or unemployed, are also noticeable in a reorientation of civic practices (so-called solidarity actions). Does solidarity action turn toward these new people, such as for instance refugees or the long-term unemployed, in need of assistance? Is there a general awareness of the transition of the Danish welfare model from universalism providing services indistinguishably to all persons in need to more conditionality?

The overall question thus is whether this new conditionality of the welfare state is also supported by general attitudes and new practices of solidarity. From a European comparative perspective, this is relevant in order to establish whether Danes still support universal welfare regimes and recognize the needs of new groups of recipients for solidarity recognized by 
the Danish population. We further wish to understand whether such traditional notions of an inclusive, service-oriented welfare state can be combined with an awareness of global solidarity challenges and possible solutions. This includes an analysis of the extent to which citizens themselves are involved in such transnational and local networks or individual forms of solidarity action.

We organize our analysis of reported solidarity practices around an alternative set of hypotheses: the first concerns support of the traditional belief systems and the notion of universal welfare, and the second concerns the conditionality of solidarity based on the notion of deservingness. In the first case, reported solidarity practices and attitudes would uphold the founding principles and distinctive traits of the Danish (Scandinavian) welfare regime. In line with the existing literature (Christoffersen et al. 2013; Jöhncke 2011), we would expect high levels of support for the welfare state and involvement in solidarity practices to be distributed equally among the population encompassing all age groups, gender, regions and ideological and political affiliations. Such a uniform pattern of solidarity would reflect the homogeneity of Danish society represented by centralized state structures. We would further expect that a centralized, strong and omnipresent welfare regime releases citizens from the need to invest in substantive support action. Danes would trust that the universal welfare state takes care of the basic needs of vulnerable groups like the unemployed, people with disabilities or refugees. Mutual support would be voluntary and not required for the subsistence of these persons in need. We would therefore expect Danish civil society to assume a subsidiary function vis-à-vis state-centered welfare: solidarity action would often supplement existing services and not be substitutive for the well-being or survival of vulnerable groups (in contrast to countries where state solidarity is lacking or inefficient). Citizens would rather opt for indirect instead of direct support actions and their solidarity would encompass several levels: trust and mutual assistance at the local and national level and a European and global problem awareness. We would ultimately expect that the universal welfare state releases forces for the mobilization of transnational solidarity, which becomes especially a target of private, individual support action and charity.

In the second case, we would be able to identify patterns of conditionality in the reported solidarity practices. We would be able to describe how Danes distinguish between different recipients of solidarity along criteria of deservingness that justify an unequal distribution of services 
and differentiated access to welfare. We would further expect that solidarity varies along the lines of the expected contributions of solidarity recipients to Danish society. An instrumental view on solidarity would thus prevail over the inclusive norms of universal welfare. In particular, we would be able to describe whether solidarity is redefined in a way that either claims of welfare chauvinism or claims of nativism become more legitimate. In the first case, we would assume that Danes support the claims that welfare benefits should become conditional on individual contributions measured in terms of 'having served' for the national community (deservingness based on merit). In the second case, Danes would support the claims that welfare benefits should be reserved only for those considered 'natives' by being born into the national community (deservingness based on ethnic and cultural bonds).

As a result of this shift from universalism to deservingness, we would further expect that solidarity would become more confrontational with citizens either supporting restrictions of welfare through the application of criteria of deservingness or opposing them. This confrontation would follow an ideological left-right cleavage, leading to the polarization of the Danish population shifting from the support of center-right or center-left parties to the political extremes. Conditionality in the reported solidarity practices would also encompass several levels, with strong preference given to the local and national enactment of solidarity and more exclusive attitudes toward European and global solidarity action. As regards patterns of transnational solidarity, we would, on the one hand, expect many Danes to be reluctant to extend welfare services to groups of European migrants or refugees and to make access of these groups conditional. On the other hand, following the new confrontational style through which solidarity is negotiated, we would expect Danes to engage in more political forms of solidarity action in direct opposition of state policies or in response to deficits of state welfare.

\section{FINDINGS}

\section{Reported Solidarity Practices}

First of all, we wish to investigate whether reported solidarity practices in Denmark reflect a new conditionality in the way Danish population distinguishes solidarity receivers as deserving or undeserving. As shown in Table 2.1, approximately half of the population (46.6\%) declares to be 
engaged in some sort of solidarity action in Denmark, but only about onefourth in the EU (23.9\%) and little more than one-third (36\%) outside the EU. In line with previous findings on the inclusiveness of Danish welfare, a relatively widespread solidarity culture in Denmark thus persists and is measurable not only at the level of attitudes but also translates into various forms of solidarity practices accounting for the needs of vulnerable groups primarily inside Denmark but also with a strong focus outside of Denmark, both in Europe and globally.

Table 2.2 shows the type of solidarity actions that people become involved in at the national level. Among the solidarity actions listed at national level, low engagement activities such as donating money is by the far the most widespread activity (28.4\% of all Danes), followed by buying or refusing to buy products in support of solidarity goals (17.5\%). High engagement activities such as donating time (12.8\%), engaging as a passive $(10.8 \%)$ or active $(9.6 \%)$ member of a solidarity organization rank lower and participating in a protest march lowest $(9.2 \%)$ among the reported solidarity activities.

Low engagement activities like donating money or consumer awareness are expectedly more widespread than more engaging activities like donating time, protesting in the streets or aligning with an organization. This is in line with our hypothesis that the availability of state help for persons in need correlates with more indirect forms of solidarity action. Solidarity

Table 2.1 Engagement in solidarity action at national, European and global level (\% participated in some form of action)

\begin{tabular}{lcc}
\hline National & $E U$ & Outside EU \\
\hline 46.6 & 23.3 & 34.5
\end{tabular}

Table 2.2 Type of solidarity action at national level (in \%)

\begin{tabular}{lc}
\hline & Participated \\
\hline $\begin{array}{l}\text { Attended a march protest or } \\
\text { demonstration }\end{array}$ & 9.2 \\
$\begin{array}{l}\text { Donated money } \\
\text { Donate time }\end{array}$ & 28.4 \\
Bought or refused to buy products & 12.8 \\
$\begin{array}{l}\text { Engaged as passive member of an } \\
\text { organization }\end{array}$ & 17.5 \\
$\begin{array}{l}\text { Engaged as an active member of an } \\
\text { organization }\end{array}$ & 9.6 \\
\hline
\end{tabular}


action is however not apolitical, as some political awareness is needed, for instance, when consumers decide as citizens to boycott particular products. Explicit political activism in support of solidarity like participation in street protests or active membership in political groups is however not widespread (Grasso 2011, 2016), that is, only one out of ten Danes engages in such activities.

Looking more closely at conditional factors of solidarity behavior, we first test a number of social structure variables. When it comes to age, we find that solidarity action at national level is equally spread over all generations, but there are greater differences between younger and older people with respect to solidarity action in the EU and outside of EU, that is, the younger generations below 35 is generally more engaged in European and global solidarity action (Table 2.3).

In other words, young people do not withdraw from national solidarity action and replace it with European and global engagement but engage more equally at all levels. There is thus no trade-off between national and European/global solidarity. The higher engagement of young people in transnational solidarity action is even more striking if one considers the necessity to invest higher resources for transnational actions, like time and money that are more easily available for elder generations. Moreover, age differences are more pronounced when it comes to solidarity within the EU. Comparing the young age group of 18-24 with the middle age group of $45-54$, their engagement in national solidarity action is identical (both $47.6 \%)$, their engagement in global solidarity action is wider $(41.1 \%$ vs. $32.8 \%)$, but the widest gap is to be found in European solidarity engagement (32.2\% vs. $20.0 \%)$.

Table 2.3 Engagement in solidarity action at national, European and global level (\% participated in some form of action) by age group

\begin{tabular}{lccc}
\hline & National & $E U$ & Outside $E U$ \\
\hline $18-24$ & 47.6 & 32.2 & 41.1 \\
$25-34$ & 50.0 & 30.3 & 37.7 \\
$35-44$ & 44.4 & 21.1 & 29.8 \\
$45-54$ & 47.6 & 20.0 & 32.8 \\
$55-64$ & 48.5 & 22.7 & 33.6 \\
65 years and older & 42.9 & 18.6 & 34.2 \\
Total & 46.6 & 23.3 & 34.5 \\
\hline
\end{tabular}


These differences are even more pronounced when comparing the young generation with the elder generation (above 65), which shows lowest engagement in EU solidarity (18.6\%) but a slight increase in global solidarity action $(34.2 \%)$. Possible explanations for this EU bias are differences in support of the EU between the age groups that translate into different patterns of national, European and global solidarity. Based on political socialization theory, we could hypothesize that perhaps generations coming of age during the time of EU consolidation and making use of EU opportunities for education, work and travel feel more solidarity at this level (Grasso 2014). Other possible explanations refer to differences in support action (like donating money, which typically involves elder age groups and is more typical for expressing global solidarity and less common as an expression of European solidarity).

There are instead no gender differences when it comes to explaining support action at all levels (Table 2.4) and only slight differences when it comes to residence (city or rural areas) (Table 2.5). On the other hand, education explains higher engagement in solidarity action at all levels (Grasso 2013), with differences more marked for European/global solidarity action (Table 2.6). Moreover, there are also important inequalities

Table 2.4 Engagement in solidarity action at national, European and global level (\% participated in some form of action) by gender

\begin{tabular}{lccc}
\hline & National & EU & Outside EU \\
\hline Male & 46.1 & 22.9 & 35.3 \\
Female & 47.0 & 23.6 & 33.7 \\
Total & 46.6 & 23.3 & 34.5 \\
\hline
\end{tabular}

Table 2.5 Engagement in solidarity action at national, European and global level (\% participated in some form of action) by place of residence

\begin{tabular}{lccc}
\hline & National & EU & Outside EU \\
\hline A big city & 48.7 & 27.0 & 36.6 \\
Suburbs or outskirts & 49.4 & 22.8 & 36.2 \\
Town or small city & 43.8 & 20.7 & 32.1 \\
Country village & 43.8 & 19.8 & 32.7 \\
Farm or home in the country-side & 50.1 & 29.6 & 37.5 \\
Total & 46.6 & 23.3 & 34.5 \\
\hline
\end{tabular}


by occupational class of chief of household with professionals participating in national actions of solidarity at $\mathbf{1 5}$ points higher than those in unskilled manual jobs (Table 2.7). Overall, we can thus conclude that solidarity action is spread relatively equally between genders and places of residence but spread unevenly in terms of social class with individuals holding more resources more likely to get involved (Grasso 2017). Accounting for these class differences is however not only income but also education, occupational opportunities and social capital (as shown in Tables 2.6, 2.7, and 2.8).

Social capital as measured through sociability (i.e. meeting friends) is associated with national level solidarity, that is, with those who meet friends regularly also most engaged in solidarity action at the national level (Table 2.8). Higher social capital does not show a higher likelihood to engage in European and global solidarity, however. Differences in European and global solidarity engagement may be explained therefore rather by the nature of the network of friends (homogeneity/heterogeneity) than by frequency of meetings.

Table 2.6 Engagement in solidarity action at national, European and global level (\% participated in some form of action) by education

\begin{tabular}{lccc}
\hline & National & EU & Outside EU \\
\hline University or higher degree & 54.6 & 30.0 & 45.9 \\
Secondary school & 48.1 & 23.9 & 35.4 \\
Less than secondary school education & 38.6 & 17.6 & 24.9 \\
Total & 46.6 & 23.3 & 34.5 \\
\hline
\end{tabular}

Table 2.7 Engagement in solidarity action at national, European and global level (\% participated in some form of action) by occupational class

\begin{tabular}{lccc}
\hline & National & EU & Outside $E U$ \\
\hline Professional or higher & 56.3 & 30.4 & 49.0 \\
Manager or senior administrator & 52.4 & 26.6 & 38.2 \\
Clerical & 42.2 & 17.0 & 30.4 \\
Sales or services & 47.9 & 22.5 & 33.3 \\
Foreman or supervisor & 46.8 & 30.1 & 41.2 \\
Skilled manual work & 46.4 & 25.5 & 31.0 \\
Semi-skilled or unskilled manual & 41.0 & 18.3 & 27.3 \\
Other (e.g. farming) & 38.2 & 21.1 & 26.7 \\
Total & 46.6 & 23.3 & 34.5 \\
\hline
\end{tabular}


Table 2.8 Engagement in solidarity action at national, European and global level (\% participated in some form of action) by social capital (frequency of meeting friends)

\begin{tabular}{lccc}
\hline & National & EU & Outside EU \\
\hline Less than once this month & 34.0 & 30.4 & 49.0 \\
Once or twice this month & 45.9 & 26.6 & 38.2 \\
Every week & 52.9 & 17.0 & 30.4 \\
Almost everyday & 47.9 & 22.5 & 33.3 \\
Total & 46.6 & 23.3 & 34.5 \\
\hline
\end{tabular}

Summing up the social structure variables, we find that solidarity behavior of the Danish population is overall rather uniform and follows expected patterns. The preferred action forms for Danes are passive activities like donating money, but still a substantial portion of the population also invests in more engaging and political forms of solidarity. Gender and residence do not impact on solidarity engagement, while there are interesting differences between age groups, educational levels and occupational classes.

Among the attitudinal patterns, it is interesting to note that strength of national identity measured in terms of attachment to one's country matters less to explain engagement in national solidarity action but more to explain European and global solidarity. People who feel least attached to Denmark as a country would still engage in national solidarity and are those most likely to engage in European and global solidarity. Whereas people who feel strongly attached to Denmark as a country are engaged in national solidarity action (even though interestingly to a lower extent that those who feel no attachment), these groups of people are the least likely to engage in European and global solidarity.

This is different when the strength of national identity is measured in terms of ethnic belonging: respondents who feel highly attached to other Danes show a very similar pattern of solidarity engagement at all levels with a clear focus on national solidarity compared to the group of respondents who feel a strong attachment to Denmark as a country. People who feel no attachment to other Danes are instead expectedly least engaged in national solidarity but do also show lower solidarity engagement at all levels compared to the group of Danes that feels attachment to Denmark as a country (Table 2.9). Strong ties of ethnic belonging thus translate into strong patterns of national solidarity as much as strong ties of territo- 
Table 2.9 Engagement in solidarity action at national, European and global level (\% participated in some form of action) by attachment to country and fellow citizens

\begin{tabular}{lcccccccc}
\hline & \multicolumn{3}{c}{ Attached to Denmark } & & \multicolumn{2}{c}{ Attached to people in Denmark } \\
\cline { 2 - 3 } & National & EU & Outside EU & & National & EU & Outside EU \\
\hline Not at all attached & 51.0 & 36.9 & 42.8 & & 38.5 & 29.8 & 31.2 \\
Not very attached & 49.5 & 34.5 & 45.8 & & 51.4 & 34.0 & 46.4 \\
Fairly attached & 50.8 & 25.9 & 37.5 & & 44.3 & 21.5 & 31.6 \\
Very attached & 45.9 & 21.5 & 33.1 & & 49.2 & 23.3 & 37.4 \\
Don't know & 15.8 & 13.6 & 15.7 & & 46.5 & 22.3 & 29.5 \\
Total & 46.6 & 23.3 & 34.5 & & 46.6 & 23.3 & 34.5 \\
\hline
\end{tabular}

rial belonging generate national solidarity. Weak ties of ethnic belonging instead translate into weak solidarity engagement at all levels, whereas weak ties of territorial belonging go hand in hand with strong solidarity engagement at all levels.

Danes who feel no or little attachment to other Danes born in the country also engage less in national solidarity action compared to Danes who feel a strong attachment to fellow Danish citizens. Yet the ratio of engagement in European and global solidarity between these two groups is the same, that is, those who feel no attachment to fellow nationals do not compensate their lack of attachment by higher engagement in European and global solidarity, while those who feel a strong attachment to their co-nationals also translate this into solidarity action toward them and engage to minor degrees in global and European solidarity. Again, we find that there is no trade-off between engagement in national and European/global solidarity, which are not exclusive but complementary. A strong feeling of solidarity with co-nationals is thus also a good predictor for engagement in global and European solidarity, while respondents who feel not attached to co-nationals show low solidarity engagement at all levels.

We further find a strong correlation with political interest (Grasso and Giugni 2016), which matters at all levels, but most when it comes to global solidarity and least when it comes to solidarity within the EU (Table 2.10). Political awareness makes it more likely that Danes engage in global solidarity and to a minor degree also national solidarity but affects least engagement in EU solidarity. 
Table 2.10 Engagement in solidarity action at national, European and global level (\% participated in some form of action) by political interest

\begin{tabular}{lccc} 
& National & EU & Outside EU \\
\hline Not at all interested & 28.8 & 14.6 & 18.0 \\
Not very interested & 40.5 & 18.9 & 27.4 \\
Quite interested & 48.0 & 21.8 & 36.2 \\
Very interested & 63.8 & 39.5 & 51.1 \\
Don't know & 21.8 & 13.8 & 17.7 \\
Total & 46.6 & 23.3 & 34.5 \\
\hline
\end{tabular}

Table 2.11 Engagement in solidarity action at national, European and global level (\% participated in some form of action) by party attachment

\begin{tabular}{lccc}
\hline & National & $E U$ & Outside EU \\
\hline Socialdemokratiet & 48.9 & 22.6 & 38.2 \\
Dansk Folkeparti & 38.5 & 16.3 & 22.0 \\
Venstre & 42.5 & 21.6 & 30.7 \\
Enhedslisten & 64.1 & 41.1 & 56.2 \\
Liberal alliance & 43.8 & 25.7 & 33.2 \\
Det Radikale Venstre & 57.6 & 34.2 & 53.2 \\
Socialistisk Folkepar & 63.4 & 29.2 & 48.2 \\
Det Konservative folk & 38.7 & 24.2 & 32.1 \\
Other party & 55.8 & 29.6 & 47.6 \\
No party & 39.3 & 16.2 & 26.3 \\
Don't know & 38.8 & 18.5 & 24.5 \\
Total & 46.6 & 23.3 & 34.5 \\
\hline
\end{tabular}

From the literature, we would expect that in a consociational democracy, like Denmark, ideological cleavages matter less and that citizens, while aligning with political parties, show similar patterns of solidarity and support for the welfare state (Christoffersen et al. 2013). This is not exactly corroborated by our data where a left-right cleavage in solidarity action is clearly visible (Table 2.11). While supporters of all political parties are involved in forms of solidarity action to some extent, we find that supporters of right and liberal parties are less engaged in solidarity action than supporters of left and social-democratic parties (Giugni and Grasso 2015). The two solidarity poles are marked by citizens who feel attached to the populist Dansk Folkeparti (Danish People's Party) (39.4\% involved in solidarity action) and citizens who feel close to the left-socialist Enhedslisten 
Table 2.12 Engagement in solidarity action at national, European and global level (\% participated in some form of action) by closeness to political party

\begin{tabular}{lccc} 
& National & $E U$ & Outside EU \\
\hline Not very close & 43.0 & 18.5 & 32.3 \\
Quite close & 51.0 & 25.3 & 37.8 \\
Very close & 54.7 & 35.6 & 46.9 \\
Don't know & 36.6 & 21.3 & 28.2 \\
Total & 46.6 & 23.3 & 34.5 \\
\hline
\end{tabular}

(Red-Green Alliance) (66.4\%). This difference between the left and the right is even more pronounced when it comes to engagement with global solidarity with the same poles formed by Danske Folkeparti $(22.8 \%$ involved in global solidarity action) and Enhedslisten (57.8\%). In the case of solidarity action within the EU, engagement is generally lowest and party differences matter less, but it is interesting to note that the two Eurosceptic parties Dansk Folkeparti and Enhedslisten form again the poles, with only $16.9 \%$ of Dansk Folkeparti supporters engaged in EU solidarity action and $42.6 \%$ of supporters of Enhedslisten.

The closer you feel connected to a political party, the more likely you are to engage in solidarity action; closeness to a political party impacts on solidarity action most in the case of global solidarity and least in the case of solidarity within the EU (Table 2.12). In general, it appears that the contours of the field of EU solidarity action are still blurred, while Danish citizens across all variables prefer to engage in solidarity nationally and to a lower extent invest in global solidarity action (the half-third-fourth model: that is, $50 \%$ national, $33 \%$ global and $25 \% \mathrm{EU})$. While Danes have a generally positive attitude toward the EU, their willingness to invest personally in solidarity action within the EU is low and, in fact, lowest among the supporters of Eurosceptic right-populist parties.

There is a slight positive bias in engagement in solidarity action among those who are more positive about EU membership (Table 2.13). The same thing is true of those who think the country benefited from EU membership (Table 2.14). On the other hand, a substantial number $(20.2 \%)$ of Danes who think that EU membership is a bad thing still engage in EU solidarity action (compared to $23.3 \%$ of the whole population and $27.6 \%$ among those who think that EU membership is a good thing). 
Table 2.13 Engagement in solidarity action at national, European and global level (\% participated in some form of action) by opinion on EU membership

\begin{tabular}{lccc}
\hline & National & $E U$ & Outside EU \\
\hline A good thing & 51.2 & 27.6 & 41.6 \\
A bad thing & 46.1 & 20.2 & 29.7 \\
Neither good nor bad & 47.0 & 23.8 & 33.8 \\
Don't know & 27.7 & 12.7 & 20.6 \\
Total & 46.6 & 23.3 & 34.5 \\
\hline
\end{tabular}

Table 2.14 Engagement in solidarity action at national, European and global level (\% participated in some form of action) by opinion on whether country benefits from EU membership

\begin{tabular}{lccc}
\hline & National & EU & Outside EU \\
\hline Benefited & 51.4 & 27.7 & 40.7 \\
Not benefited & 45.7 & 20.9 & 31.1 \\
Don't know & 36.9 & 16.8 & 25.4 \\
Total & 46.6 & 23.3 & 34.5 \\
\hline
\end{tabular}

Table 2.15 Engagement in solidarity action at national, European and global level (\% participated in some form of action) by support for EU debt relief

\begin{tabular}{lccc}
\hline & National & $E U$ & Outside EU \\
\hline Strongly disagree & 37.5 & 13.7 & 23.4 \\
Disagree & 44.1 & 21.0 & 27.9 \\
Neither & 47.2 & 22.6 & 34.7 \\
Agree & 57.4 & 32.2 & 48.5 \\
Strongly agree & 65.9 & 44.5 & 58.4 \\
Don't know & 31.2 & 14.4 & 22.8 \\
Total & 46.6 & 23.3 & 34.5 \\
\hline
\end{tabular}

Moreover, opponents of EU redistribution policies engage less in solidarity action at all levels, which either reflects a general non-solidary attitude or a preference of altruistic forms of solidarity action over redistributive ones (Table 2.15). There does not seem to be a trade-off between solidarity at different levels.

Finally, personal perceptions of justice tend to be linked to a strong focus on engagement in national solidarity action (Table 2.16). Those 
Table 2.16 Engagement in solidarity action at national, European and global level (\% participated in some form of action) by what the respondent feels they receive relative to others in their country

\begin{tabular}{lccc}
\hline & National & $E U$ & Outside EU \\
\hline More than your fair share & 51.5 & 41.9 & 51.9 \\
Your fair share & 49.1 & 22.7 & 37.9 \\
Somewhat less than your fair share & 49.3 & 26.7 & 34.4 \\
Much less than your fair share & 47.6 & 24.0 & 31.9 \\
Don't know & 30.5 & 13.4 & 16.7 \\
Total & 46.6 & 23.3 & 34.5 \\
\hline
\end{tabular}

who thought they received less than their just share would still be willing to invest in national solidarity, and to some extent global solidarity, but are less likely to engage in EU solidarity action. The biggest differences between those who feel they have more or about their fair share and those who feel they get less are in EU and global solidarity.

Our results have shown that a substantial number of Danes who feel strongly attached to their country would still engage in European and global solidarity action. This confirms findings from other studies, which have shown that identities expressed at different levels are not exclusive: people can feel attached to their nations but at the same time feel also belonging to a European and global community (Risse 2010). This difference between attitudinal variables and engagement in solidarity action is weakest in the case of support of EU membership.

'Cosmopolitans' and 'Europeanists' differ to some degree from 'nationalists' but are not fundamentally different in their engagement in transnational solidarity action. Instead, we find a strong partisan division line with supporters of extreme left parties being strongly engaged in transnational solidarity and supporters of extreme right parties weakest. This division is however less visible when comparing supporters of the two centermainstream parties Social-Democrats and Venstre, showing very similar patterns of national and European solidarity engagement and only some minor deviation in the case of global solidarity engagement. Left-leaning and right-leaning Danes are thus clearly distinct in their solidarity behavior, while the center-leaning majority displays very similar patterns of solidarity engagement. If polarization happens, this takes place mainly at the fringes of the political spectrum. Given the strong mobilization potential of Dansk Folkeparti with a potential to affect the whole population (as in 
the case of the refugee crisis), such forms of enhanced solidarity contestation still mark an important shift from the consensus orientation that has traditionally characterized Danish society.

\section{CONCLUSION}

In this chapter, we have identified a number of factors that condition solidarity practices in Denmark. By putting to the test the principled universalism of the Danish welfare state, we found that solidarity practices are relatively widespread across the population in Denmark and that Danes in all age groups and independently of gender and residence engage in solidarity above all at the national level but to significant degrees also at global and European level (the half-third-fourth model: that is, $50 \%$ national, $33 \%$ global and $25 \% \mathrm{EU}$ ). To the extent that a formally universal welfare state is upheld, Danes also continue to be proud of their high-taxed, universal welfare regime, even though in practice many welfare services have become conditional, and criteria of deservingness are applied when deciding about the needs of diverse groups of people. In line with our hypothesis, we can thus conclude that the belief in the value of universal welfare is still deeply ingrained in the Danish mindset, but the question of how to redistribute welfare and cover the needs of specific groups is increasingly contested.

In line with this new conditionality in the implementation of statecentered welfare services, we found that also reported solidarity practices and attitudes distinguish different degrees of deservingness for deciding on the access to welfare. Our findings in this sense rather support our second hypothesis reflecting a reality of conditional solidarity and unequal access to welfare that is justified by criteria such as ethnic belonging or expected contributions of solidarity recipients to Danish society. An instrumental view on conditional solidarity prevails at the level of reported solidarity practices and restrictive attitudes toward specific groups in need (in particular migrants, refugees and long-term unemployed), while in terms of general beliefs, the inclusiveness of universal welfare is still upheld as a counterfactual norm that distinguishes Denmark in Europe and in the world. This new conditionality of solidarity attitudes and practices is partly explained by socio-structural variables such as education and occupational class with less resourceful individuals less likely to engage in different forms of solidarity action. Apart from these socio-structural variables, we also considered a number of attitudinal variables. Among those, identity (as measured through territorial and ethnic belonging) matters less, but 
party affiliation is found to be a strong predictor for differences in solidarity behavior with adherents of the right-populist Danish People's Party engaged less in solidarity at all levels and the sympathizers of the RedGreen Alliance engaged most. In future analyses, the conditionality of solidarity needs to be also tested with regard to manifestations of solidarity toward different vulnerable groups in society. This would allow for a more systematic identification of conditional factors of solidarity in relation to different levels (national, European, global) and reference groups (unemployed, people with disabilities and immigrants/refugees) which could be developed further in future work.

\section{Notes}

1. See, for instance, their statement on 'Europe in the crisis' with an explicit reference to solidarity and welfare in the wider Europe and the world (http://org.enhedslisten.dk/tema/europa-i-krise-fakta-og-muligheder last accessed May 10, 2017).

2. See our overview of most recent policy changes and restrictions in the field of unemployment, disabilities and immigration/asylum in Duru et al. (forthcoming).

3. Comparative GDP per capita indices over the period 2008-2016 are provided by Eurostat (see http://ec.europa.eu/eurostat/tgm/table.do?tab=ta ble\&init $=1$ \&language $=$ en $\&$ pode $=$ tec 00001 \&plugin $=1$ ).

4. http://www.dst.dk/da/Statistik/nyt/NytHtml?cid=22577.

5. http://ec.europa.eu/eurostat/statistics-explained/index.php/ Unemployment_statistics\#Recent_developments_in_unemployment_at_a_ European_and_Member_State_level.

6. https://www.nyidanmark.dk/NR/rdonlyres/D7322BD4-B6ED-43D7AFEA-00F597BE0800/0/statistical_overview_2013.pdf.

7. Trust in political institutions and impact on the crisis on political attitudes are measured by Standard Eurobarometer (http://ec.europa.eu/commfrontoffice/publicopinion/index.cfm).

8. http://www.humanityinaction.org/knowledgebase/59-the-danishillusion-the-gap-between-principle-and-practice-in-the-danish-welfare-system.

\section{REFERENCES}

Banting, K., \& Kymlicka, W. (2017). The Strains of Commitment: The Political Sources of Solidarity in Diverse Societies. Oxford University Press.

Calhoun, C. (2002). Imagining Solidarity: Cosmopolitanism, Constitutional Patriotism, and the Public Sphere. Public Culture, 14, 147-171. 
Christoffersen, H., Beyeler, M., Eichenberger, R., et al. (2013). The Good Society: A Comparative Study of Denmark and Switzerland. Springer Berlin Heidelberg. Duru, D. N., Spejlborg Sejersen, T., and Trenz, H. J. (forthcoming). The Best Welfare System in the World? The Danish Welfare State, Transnational Solidarity, and Civil Society in Times of Crisis. Basingstoke: Palgrave Macmillan. English, P., Grasso, M. T., Buraczynska, B., Karampampas, S., \& Temple, L. (2016). Convergence on Crisis? Comparing Labour and Conservative Party Framing of the Economic Crisis in Britain, 2008-2014. Politics \& Policy, 44(3), $577-603$.

European Commission. (2014). EU Employment and Social Situation. Quarterly Review. Recent Trends in the Geographical Mobility of Workers in the EU. Luxembourg: Publications Office of the European Union. Retrieved January 22, 2018, from http://ec.europa.eu/employment_social/employment_analysis/quarterly/essqr-2014june-suplmobility.xls.

Giugni, M., \& Grasso, M. T. (2015). Environmental Movements in Advanced Industrial Democracies: Heterogeneity, Transformation, and Institutionalization. Annual Review of Environment and Resources, 40, 337-361.

Grasso, M. T. (2011). Political Participation in Western Europe. D.Phil. Thesis, Nuffield College, University of Oxford.

Grasso, M. T. (2013). The Differential Impact of Education on Young People's Political Activism: Comparing Italy and the United Kingdom. Comparative Sociology, 12(1), 1-30.

Grasso, M. T. (2014). Age-Period-Cohort Analysis in a Comparative Context: Political Generations and Political Participation Repertoires. Electoral Studies, 33, 63-76.

Grasso, M. T. (2016). Generations, Political Participation and Social Change in Western Europe. London: Routledge.

Grasso, M. T. (2017). Young People's Political Participation in Times of Crisis. In S. Pickard \& J. Bessant (Eds.), Young People Regenerating Politics in Times of Crisis. London: Palgrave Macmillan.

Grasso, M. T., Farrall, S., Gray, E., Hay, C., \& Jennings, W. (2017). Thatcher's Children, Blair's Babies, Political Socialisation and Trickle-Down ValueChange: An Age, Period and Cohort Analysis. British Journal of Political Science. https://doi.org/10.1017/S0007123416000375.

Grasso, M. T., \& Giugni, M. (2016). Protest Participation and Economic Crisis: The Conditioning Role of Political Opportunities. European Journal of Political Research, 55(4), 663-680.

Habermas, J. (2013). Democracy, Solidarity and The European Crisis. Retrieved from http://www.social-europe.eu/2013/05/democracy-solidarity-and-theeuropean-crisis- $2 /$.

Hall, P. A. (2017). The Political Sources of Solidarity. In K. Banting \& W. Kymlicka (Eds.), The Strains of Commitment: The Political Sources of Solidarity in Diverse Societies (pp. 201-233). Oxford: Oxford University Press. 
Jensen, P. H., \& Torpe, L. (2016). The Illusion of Universalism: The Case of the Danish Welfare State. Politiche Sociali, 3, 403-420.

Jöhncke, S. (2011). Integrating Denmark: The Welfare State as a National(ist) Accomplishment. In K. F. Olwig \& K. Paerregaard (Eds.), The Question of Integration, Immigration, Exclusion and the Danish Welfare State. Newcastle upon Tyne, UK: Cambridge Scholars Publishing.

Jørgensen, M. B., \& Thomsen, T. L. (2013). Crises Now and Then-Comparing Integration Policy Frameworks and Immigrant Target Groups in Denmark in the 1970s and 2000s. International Migration \& Integration, 14, 245-262.

Larsen, J. E., Bengtsson, T. T., \& Frederiksen, M. (2015). The Danish Welfare State. Basingstoke: Palgrave Macmillan.

Martinsen, D. S. (2005). The Europeanization of Welfare-The Domestic Impact of Intra-European Social Security. JCMS: Journal of Common Market Studies, $43,1027-1054$.

Risse, T. (2010). A Community of Europeans? Transnational Identities and Public Spheres. New York: Cornell University Press.

Spejlborg Sejersen, T., \& Trenz, H. J. (2017). Transnational Solidarity in Danish Civil Society, in: TransSOL: Integrated Report on Integrated Report on Collective Forms of Solidarity at Times of Crisis. Work Package 4: Collective Forms of Solidarity at Times of Crisis, 20-42. Retrieved January 22, 2018, from http:// transsol.eu/files/2017/12/WP4-Integratedreport-final.pdf.

Stjernø, S. (2004). Solidarity in Europe: The History of an Idea. Cambridge: Cambridge University Press.

Strøby-Jensen, C. S. (2011). The Flexibility of Flexicurity: The Danish Model Reconsidered. Economic and Industrial Democracy, 32(4), 721-737.

Temple, L., Grasso, M. T., Buraczynska, B., Karampampas, S., \& English, P. (2016). Neoliberal Narrative in Times of Economic Crisis: A Political Claims Analysis of the UK Press, 2007-2014. Politics \& Policy, 44(3), 553-576.

Open Access This chapter is licensed under the terms of the Creative Commons Attribution 4.0 International License (http://creativecommons.org/licenses/ by $/ 4.0 /$ ), which permits use, sharing, adaptation, distribution and reproduction in any medium or format, as long as you give appropriate credit to the original author(s) and the source, provide a link to the Creative Commons license and indicate if changes were made.

The images or other third party material in this chapter are included in the chapter's Creative Commons license, unless indicated otherwise in a credit line to the material. If material is not included in the chapter's Creative Commons license and your intended use is not permitted by statutory regulation or exceeds the permitted use, you will need to obtain permission directly from the copyright holder.

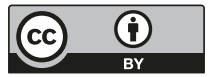

